\title{
The internationalization process model through the lens of the global color picture tube industry
}

\author{
Anil Khurana ${ }^{a, *}$, Brian Talbot ${ }^{b, 1}$ \\ ${ }^{a}$ Boston University School of Management, 595 Commonwealth Avenue, Boston, MA 02215, USA \\ ${ }^{\mathrm{b}}$ University of Michigan Business School, Ann Arbor, MI 48109, USA
}

\begin{abstract}
Internationalization theories from economics and international business disciplines suggest that products are launched, and production facilities established, sequentially in industrialized, newly industrialized, and finally, in developing countries. From a firm level perspective, operations management researchers have proposed descriptive models of generic roles of international factories. But little has appeared in the economics, international business, or operations management literature that compares these two views or provides much empirical evidence to support divergent claims. In this paper, we compare both perspectives and shed insight into factory roles through a detailed examination of data on plant practices and performance in the global picture tube industry. Our analysis suggests that existing theory and descriptive models do not possess enough explanatory power to adequately predict or describe the dynamics of product and production loci today. We highlight the need for a new theory by contrasting today's global business realities with those of yesteryears. (C) 1998 Elsevier Science B.V. All rights reserved.
\end{abstract}

Keywords: Color picture tube industry; Internationalization process model; Global manufacturing

\section{Introduction}

The primary purposes of this paper are to inform researchers and managers of some of the shortcomings of traditional management theory as it applies to global manufacturing, and to provide a richer understanding of current global manufacturing management practices. Through the use of secondary industry data and primary plant-level manufacturing data from the global color picture tube industry, we argue

\footnotetext{
* Corresponding author. Tel: + 1-617-353-2287; fax: + 1-617353-4098; e-mail: akhurana@acs.bu.edu

${ }^{1}$ Tel.: +1-313-764-6842; fax: +1-313-763-5688; e-mail: btalbot@umich.edu
}

that a key theory of international business, the internationalization process model-which comprises the international product lifecycle model (Vernon, 1966, 1979) and the Uppsala internationalization model (Johanson and Vahlne, 1977, 1990)—does not adequately explain current industry manufacturing practices. We frame our discussion and results within the relevant literature in global manufacturing strategy (e.g., Ferdows, 1989) and the strategic typologies and taxonomies literature (e.g., Miles and Snow, 1978; Miller and Roth, 1994). This approach permits us to link the relevant international business and operations management literatures, and illustrate shortcomings of both the theory of the former and the descriptive models of the latter. 
The paper is organized as follows. Section 1 presents an overview of the relevant literature. Theory based predictions are stated and subsequently tested. Section 2 describes the research design and methodology. Results are presented in Section 3 based on cluster analysis, regional comparisons, comparisons of performance and practices across plant roles, and the canonical functions that explain and predict the clusters of plant roles. A discussion of our results is provided in Section 4, and conclusions are given in Section 5.

\subsection{Background}

One of the key theories that seeks to explain and predict globalization is the theory of foreign direct investment (FDI) (see Melin, 1992 for a classification of globalization theories). FDI theory suggests that investments in foreign countries are a function of the nature of the advantages that multinational corporations (MNCs) expect they will realize by investing outside their home borders. The field has broadly come to accept the notion that such advantages accrue from ownership (e.g., technology, skills, patents), location (e.g., natural resources, low-cost labor, transportation), and the ability to internally leverage capabilities (Hymer, 1976; Vernon, 1974; Kojima, 1978, 1982; Dunning, 1988). An important element of this theory, one that we use in this paper, focuses on the dynamic process of internationalization (Melin, 1992). Two oft-cited and closely related models of internationalization are the international product lifecycle model (IPLC) (Vernon, 1966, 1971, 1974, 1979) and the Uppsala internationalization process model (Johanson and Vahlne, 1977, 1990). Although developed in the 1960s and 1970s, and questioned as to their explanatory power as early as 1981 (Vernon, 1981, pp. 519, 520), both models still exert considerable influence on the field (Melin, 1992).

The IPLC model focuses on the location of production activities in a global market in the context of technological know-how, demand, scale economies, and labor costs (Vernon, 1966, p. 190). It presents an individual firm's perspective of international investment theory, one that is based on the product lifecycle. The introduction stage is domestic, having its orientation in the country where the product was developed (generally industrialized). Exports to other industrialized countries may support scale economies. During the growth stage, exports increase, and foreign investments in manufacturing plants are made in countries with an expanding demand for the product. In the maturity stage, when major markets are saturated and the product standardized, manufacturing is relocated to countries with low labor costs (generally, newly industrialized countries-NICsand developing countries). Finally, in the stage of decline, manufacturing, and in some cases even demand, leaves the industrial country which was home to the original innovation (Vernon, 1966).

The Uppsala internationalization process model supplements the IPLC model by theorizing about the process of internationalization in the context of market presence, not just in the context of production. The logical steps of international behavior are similar to the stages of the IPLC model, going through acquisition, integration, and use of knowledge about foreign markets and operations (Johanson and Vahlne, 1977). For individual firms, the key is to reduce the 'psychic' distance (Melin, 1992, p. 103) by first taking on familiar and close-by markets so as to minimize perceived market uncertainty (Johanson and Vahlne, 1990).

The basic question we raise in this paper is whether the IPLC and Uppsala internationalization models (henceforth, collectively referred to as IPUP models) are still valid today. The world has changed in a number of fundamental ways since these models were developed: communism has collapsed; global operations are the norm in many industries; ${ }^{2}$ there are striking similarities today between N. American, European, and Japanese outward flows of FDI considering how different they were only a few years ago (Ohmae, 1985; Dunning, 1988); and, countries as diverse as China, Poland, Korea, Singapore, and Taiwan have made dramatic economic progress in the last decade. In addition, global coordination and networking have improved tremendously in the past few years (Bartlett and Ghoshal, 1989; Taylor, 1991).

\footnotetext{
${ }^{2}$ For example, the applicability of the IPLC model appears to be limited if new products are developed in companies that already have considerable operations in foreign countries (see Vernon, 1979; Melin, 1992, p. 103).
} 
Do the IPUP models hold true in this era of global factory networks where each factory may have a unique mission and role, and where the political, technological, and economic landscape has changed so much?

\subsection{The internationalization models applied to man- ufacturing operations}

While there has been substantial research on the nature of internationalization, there has been only a limited effort to translate this into implications for manufacturing strategy and decision-making, possibly because of the dominance of economists among international business researchers, and also possibly because of the traditionally 'passive' nature of manufacturing in a business unit's strategy (Hayes and Wheelwright, 1984, p. 396, suggest that in most companies, manufacturing has only a passive roleStages 1 and 2-and that there are very few companies that are in Stage 3 or 4). Yet, an important aspect of manufacturing strategy is the notion that global and business strategy lead to a functional manufacturing strategy, which in turn leads to particular actions and practices (Skinner, 1969; Wheelwright, 1978; Hayes and Wheelwright, 1984; Hamel and Prahalad, 1985; Anderson et al., 1989; Hill, 1989).

The logic of the IPUP models implies that plants located in leading industrialized countries (US, Europe) ought to excel at innovation, frequently bringing out new products and processes. Plants in other industrialized countries can be expected to be good at managing and stabilizing technology and processes. The model also suggests that plants in the NICs can be expected to be average on process performance, but lag on innovation. Finally, companies and plants in developing and least developed countries (LDCs) can be expected to be low performers on virtually every dimension, except possibly cost.

The above brief classification of factory manufacturing emphasis and performance is restated as predictions of regional plant manufacturing practices.

IPUP Prediction la: North American and leading European plants (by location) will excel at innovation; NIC plants will be averaged on process man- agement and performance, and lagging on innovation; LDC plants will be low performers.

IPUP Prediction $1 b$ : Plants in the US, Europe, and Japan will be equally sophisticated on technology practices. NIC plants will lag US, European, and Japanese plants on both technology and management practices.

\subsection{Plant roles in MNCs}

Both strategy and operations management researchers suggest that a business unit's manufacturing role ought to be consistent with its business and manufacturing strategy and that organizational units may be assigned different roles for strategic reasons. (See, e.g., Miller and Friesen, 1977 and Miles and Snow, 1978 for research on strategic archetypes, or Skinner, 1974; Richardson et al., 1985; Miller and Roth, 1994 for a more operations-driven perspective). Here, to facilitate our analysis, we adopt Miller and Roth's operations strategy typology, since it is one that comes closest to being applicable at the level of the factory. Their taxonomy includes 'innovators', 'marketeers', and 'caretakers'. 'Innovators' have a superior ability to introduce new products and make design changes, excel at both conformance quality and product performance, and do not emphasize price as much as other groups. Given their emphasis on short product lifecycles, such business units demonstrate the characteristics of startup firms, in the early stages of the product lifecycle. 'Marketeers' emphasize a variety of market-oriented capabilities such as broad distribution, broad product line, speed, after-sales service and volume flexibility, though they also excel at conformance quality and product performance, and are moderately price conscious. They pursue manufacturing strategies characteristic of businesses in more mature phases of the lifecycle; thus, there is a greater emphasis on manufacturing process reliability, quality control, and ongoing improvement. Finally, 'caretakers' generally cater only to the minimum standards of competition and focus on low price. They act as if they are in the declining stages of the product lifecycle.

The above classification of strategic roles can be mapped on to the description of the IPUP models of the internationalization process which leads us to our second IPUP prediction. 


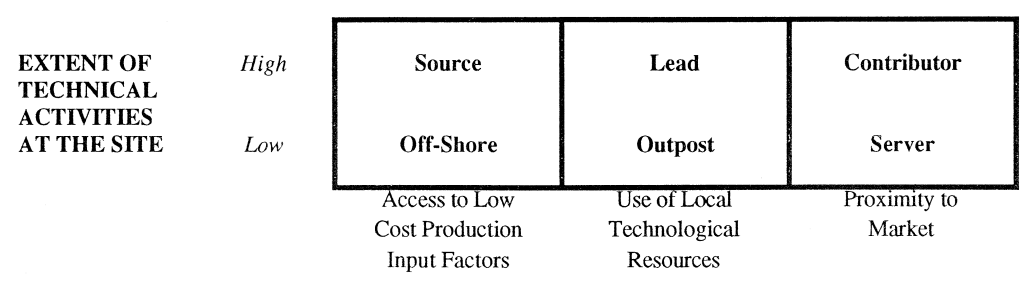

PRIMARY STRATEGIC REASON FOR THE SITE

Fig. 1. Generic roles of international factories.

IPUP Prediction 2: US, Japanese, and leading European plants (by location) will be 'innovators', other industrialized country plants (and some in NICs) will be 'marketeers', while some NIC and developing country plants will be 'caretakers'.

A second relevant stream of research focuses on multiplant networks, and the assignment of different roles in such networks (for a discussion of foreign subsidiary roles, see Bartlett and Ghoshal, 1989, p. 98). ${ }^{3}$ For example, Ferdows (1989) presents a framework for international factory networks as an extension of the notions of multiple and evolving plant roles. He suggests that the strategic role of international factories can be defined on the basis of two dimensions: (i) the primary reason for establishing the site, and (ii) the extent of technical activities performed at the site. This leads to six generic roles for international factories, as shown in Fig. 1 below.

Ferdows posits that these roles evolve over time such that 'off-shore' factories become 'source' factories, 'servers' become 'contributors', and both 'source' and 'contributors' ultimately become 'lead' factories, though that is not necessarily desirable. If we combine Ferdows' model with the IPUP model, we can argue that most MNCs would prefer to locate

\footnotetext{
${ }^{3}$ While the assignment of different subsidiary and plant roles in a network itself is interesting, multiplant and inter-subsidiary coordination within a network is also likely to influence the manner in which such roles are assigned and evolved. For example, even in a domestic setting, a multiplant study of food establishments revealed that gaps in performance result from a lack of interplant exchange and coordination (Chew et al., 1989). Such coordination is difficult in the global setting; even the apparently simple exercise of transfer of best practices is not easy (Szulanski, 1995).
}

'lead' factories in their home countries, and would establish sites in other countries as the product becomes more international. Plants in these 'other' countries would play different roles, depending on their location, and the timing in the product lifecycle (Vernon, 1966).

These arguments lead to more predictions.

IPUP Prediction 3a: Most 'lead' factories will be located in the home countries of US, Japanese, and leading European plants.

IPUP Prediction 3b: 'Contributors' / 'source' factories will generally be located in 'non-home' countries of advanced industrialized countries, and in some NICs.

IPUP Prediction 3c: Most 'offshore' factories will be located in LDCs and NICs; 'contributor' factories will not follow any consistent pattern of location.

\subsection{Research issues and approach}

The above review of the literature and our arguments about the form that global manufacturing is expected to take enable us to state the core IPUP prediction.

Core Prediction: The IPUP models, as applied to global manufacturing, will explain factory practices and plant roles in different regions.

The basic approach we take to evaluate the relevance of the internationalization models is to analyze whether: (a) there are regional differences in performance and practices as predicted by the IPUP models; (b) the global distribution of plant roles is consistent with the IPUP models; and (c) the global 
distribution of plant roles (i.e., 'home' vs. 'away') is consistent with the IPUP models and Ferdows' model.

When measuring plant 'strategy', we weigh the pros and cons of using 'strategy as intent' (planned behavior) (Mintzberg, 1992) or 'strategy as action' (actual behavior) (Wrapp, 1967; Mintzberg, 1978). While strategic plans are important for understanding the dynamic nature of plant roles, they are a vision for the future, and do not reflect current practice. Mintzberg and others suggest that it is managerial action, not merely managerial intent, that reflects an organization's realized (as opposed to planned) strategic emphasis. Though we lean towards 'strategy as action', we recognized that in our context, plant roles are best measured both by 'observed' and 'intended' behavior. Thus, we analyze measures of competitive priorities as well as factory practices.

\subsection{An industry-focused study}

The empirical data used for this paper come from a larger study of industry practices and competitiveness in the global color picture tube industry (Details are given in Section 2.1). This industry was chosen for a number of reasons: it is an important and mature global industry that has not been studied extensively, which is facing a major technological discontinuity in the form of flat panel displays. Further, given the emergence of Japanese manufacturing organizations as world class manufacturers (Womack et al., 1990), our intent was to select an industry in which there was a significant Japanese manufacturing presence.

One question that needs to be addressed is why an industry study and not a cross-sectional study? We cite two major reasons for our choice, similar to those cited by Garvin (1988) in his study of the air conditioning industry. The first is that cross-sectional studies are often confounded by industry-specific factors, and thus require a larger sample size for the same statistical power. Second, an in-depth industry study enabled us to understand the industry, processes, and management practices in considerable detail, and permitted us to gain an understanding of specific company and plant level strategies. Yet, an industry study also has weaknesses, with questionable generalizability being the key shortcoming. Short of executing a massive cross-sectional and time series study we cannot make rigorous claims about generality. However, based on our understanding of the industry context, we feel confident that our results are generalizable to similar mature, technologically sophisticated industries (Khurana, 1994).

\section{Research methods}

This section gives a brief overview of the research approach. Specifically, we describe the industry, our research design, the approach to the analysis undertaken for this paper, a description of the respondents and the basic data, and finally, the key measures used in this paper.

\subsection{Industry context}

Picture tubes or cathode ray tubes (CRTs) are the display devices used for television, computer monitors, radar screens, and medical display screens (such as X-ray or ultrasound screens), and have been in commercial use since the late 1920s (Keller, 1991). A mature product, picture tubes have passed through the basic technology and product lifecycles (see, e.g., Anderson and Tushman, 1990; Suarez and Utterback, 1995). Round tubes, rectangular tubes, large size tubes using stronger materials - the industry has seen it all (see Khurana, 1994 for details on picture tube evolution). The product lifecycle has also gone through its paces, especially in the US and Europe, with the initial era of startup (1949-1960), followed by the era of growth (1961-1975), and the current era of maturity (1976-current), with some people arguing that the next technological discontinuity has already occurred, with the increasing use of flat-panel displays. Yet, this industry continues to be innovative on both product and process. The existence of these product and process lifecycle phases is supported by observing the distribution of the number (and ownership) of tube manufacturing firms in the US from fewer than 10 immediately after W.W.II (all American owned), to a peak of over 60 in 1957 (American and foreign owned), to fewer than 10 today (none American owned) (Suarez and Utterback, 1995; Khurana, 1994).

Simultaneously, as the product lifecycle was progressing, there was also a diffusion of the technol- 
ogy, industry practices, and manufacturing capabilities across the world, not inconsistent with Vernon's traditional international product lifecycle model (Vernon, 1966). Thus, whereas the initial developments took place in the US, subsequent developments spread quickly to Europe, with firms such as Philips, Siemens and Nokia joining the competition in the 1950s. Japanese companies such as Sony, Matsushita, and Toshiba entered the market somewhat later, in the late 1960s and 1970s. Global maturity was achieved in the late 1970s. During this last phase (late 1970s), manufacturing capabilities were critical, and firms that were unable to maintain manufacturing quality and product design performance, or failed to invest in critical manufacturing technologies, did not survive. Thus, most of the surviving companies today, e.g., Sony, Matsushita, Philips, Thomson, and Toshiba, have a strong manufacturing focus.

Today, the global color picture tube industry is in its mature phase, marked by cut-throat competition (in fact, the industry seems to be following the path followed by the TV industry, with only a lag of a few years). The main players are European, Japanese, and Korean. There are fewer than 65 color picture tube factories and fewer than 30 key companies in the whole world that manufacture color picture tubes. Of these, 10 factories are in China and the ex-USSR (at the time this study was initiated in 1992, these facilities were explicitly excluded from the study because of political and economic turmoil and the consequent inaccessibility of the plants. Between 1993-1995, we have been able to obtain data from some of these plants). Also, the industry values world class manufacturing practices, and we have observed that most companies and factories have been committed to quality and world class standards. Our investigation uncovered the fact that nearly 35 factories have been closed during the past decade as a result of industry restructuring caused by the entry of more efficient Japanese and Korean factories.

\subsection{Research design}

This research was conducted in three phases. In Phase One, a detailed study of quality and factory management approaches at one picture tube company was carried out. Both quantitative data from company and factory archives, and qualitative data (based on interviews with more than 30 managers, engineers, and supervisors) were analyzed for both strategic and operational issues. Secondary data were also collected and analyzed. In Phase Two (19921993), we visited 10 color picture tube factories in N. America, Europe, and Japan, and in 1994 we visited eight plants in E. Europe, China, and India. A semi-structured questionnaire was used during these site visits to compare practices, identify trends, and develop items for the subsequent mail survey. In Phase Three (1993-1994), a detailed study of quality and manufacturing practices in the color picture tube industry was executed using four detailed mail questionnaires (one each for the plant, production, quality, and engineering manager at each plant) that were designed on the basis of prior research and the field interviews. A total of 48 out of 53 extant plants in the noncommunist countries responded to the questionnaires, giving a $91 \%$ population response, thus making it a near-census of the industry. Subsequently, in mid-1994, we obtained access to several of the plants in Eastern Europe and China, and data from another eight color picture tube factories in Eastern Europe, China, and ex-USSR were obtained. Thus, we now have data from 54 factories worldwide (of a total of 63 known existing factories).

\subsection{Analysis approach}

Much of the evidence presented in this paper is based on data collected in phase three of our research, though wherever necessary, evidence is presented from our field studies. We execute the data analysis for this paper in five steps. First, regional comparisons on several dimensions are carried out (Section 3.2). Prediction 1 is tested using these results. Second, we empirically define plant roles based on the competitive priorities described by the plants using cluster analysis (Section 3.1). The cluster analysis-derived plant roles are cross-validated with our field studies' results. Comparisons of plant strategy, performance (both end and intermediate measures are included), and management practices for the different plant role clusters are presented (Section 3.3). Third, we use a canonical discriminant analysis to describe the two key discriminant functions that explain the basis for the above clustering (Section 
3.4). Our fourth step is to compare the distribution of these plant role clusters by region, both by factory location and ownership (Section 3.5). This analysis reveals facts about the manner in which different regions use factories in different roles. This analysis enables us to test for Prediction 2. Prediction 3 is also partially tested with these results. Fifth, we carry out the same analysis for plants in the 'home' country vs. those not in the 'home' country ('away') to understand how different companies assign and use plant roles (Section 3.5).

\subsection{Respondents}

We initially defined the population for our research as all color picture tube factories outside of the ex-communist bloc countries (China, ex-USSR, and E. Europe). Black-and-white, monitor-only, and tube salvage manufacturers were excluded. This left 53 factories belonging to 23 companies located in more than 20 countries. The five non-responding factories belong to two Japanese companies and one European company. Secondary data on plant size, company size, ownership, location, and product mix for these five factories and companies did not reveal any systematic bias, either at the company level, or at the plant level (chi-square test was not significant).

An important question that we raised early in the research was whether plants belonging to the same company were indeed different, statistically and otherwise. Most of the managers that we interviewed, especially the non-Japanese managers, saw major differences in how the plants within their company were operated and managed. For Japanese plants, the general opinion (among managers and academics familiar with Japanese manufacturing management whom the authors interviewed), was that plants located in Japan and belonging to the same company were likely to be quite similar in their management policies, though they would have different kinds of production equipment of different ages, and manufacture different generations of products or tube sizes. Our analysis of basic descriptive data (using ANOVA) from the Japanese plants reveals that plants even within the same company are different, not only on the level and type of production equipment automation, product types, and the individual plant experiences with the introduction of automation, but also on performance parameters and factory practices ( $F$-value is not significant for performance variables). This confirms our contention that plants in multi-plant business units are statistically independent, which permits subsequent statistical analysis using the factory as a unit of analysis. This result is also consistent with what we observed as real differences on factory visits.

\subsection{Key measures for this study}

Four key sets of measures are used for this paper. The first set of measures assess the plant's competitive priorities. The key competitive priorities selected for this analysis are quality, flexibility, price, product/process innovation, and future leadership in innovation. Other priorities such as delivery, dependability, speed, and after-sales service were considered, but dropped since our interviews indicated they are not important differentiators in this industry. Additive scales are used for quality, innovations, and future leadership in innovation; single-item scales are used for flexibility and price. Quality (QUALITY) is an aggregate construct (thus, a test such as Cronbach's alpha was not considered appropriate or necessary) measured as the average of five questionnaire items, all 5-point scales: (i) Top management emphasis on quality as a key priority, (ii) Priority rank for tube design performance, (iii) Priority rank for conformance quality, (iv) Priority rank for factory yields, and (v) Tube performance in comparison to competitors. Flexibility (FLEXIBILITY) is measured as the extent of tube variety possible at the factory (recoded to a 5-point scale from original data). Price (PRICE) is also a single-item measure based on a comparison of the price relative to competitors. New product/process innovation capability (INNOVATE) is measured as the average of the frequency of (i) new tubes or designs, (ii) product design changes, and (iii) process design changes (Cronbach's alpha of 0.7). Finally, future leadership in innovation (LEAD-INNOVATOR) is measured on the basis of whether the factory general manager had planned or had thought of introducing monitor tubes, LCDs, and/or flat-panel active matrix screens.

The second set of measures pertain to performance (both end outcomes and intermediate measures). Two operations-related end outcomes are measured-quality and productivity. Two measures 
of quality are used. The first is a yield indicator-the average material consumption (per 1000 good tubes) of four key tube components (MAT-QUAL); the second is customer rejects (REJECTS) a self-reported measure, which we corrected for regional differences in standards (though these differences are found to be minor). Productivity is measured as labor productivity, in terms of average tubes produced per labor-hour, with corrections being made for tube size, and product mix (PRODUCTIVITY). In addition, a number of bottom-line type measures, such as return on investment or sales (ROI/ROS), are used. A number of derived measures were also obtained, e.g., improvement in reject rates over the past 4 years (REJ-IMP). The intermediate performance measures include measures such as work-in-process inventory, equipment breakdowns, capacity utilization, and manufacturing cycle time.

We draw upon several streams of literature to identify the key factory practices. In particular, we focus on the quality literature (Garvin, 1988; Benson et al., 1991), the manufacturing strategy literature (Hayes and Wheelwright, 1984), the manufacturing productivity literature (Schmenner, 1991), and the manufacturing practices literature (Schonberger, 1986; Womack et al., 1990). The factory practices identified by these literature streams can be broadly classified into factory architecture (e.g., automation level, manufacturing variety) and factory practices. Thus, we call the third set of measures factory architecture variables. In addition to factors identified in prior research, we also describe the basic structure of the factory as part of the factory 'architecture', by using such measures as age, capacity, and product mix.
The fourth and final set of measures describe factory management practices. For each of these measures, the analysis presented in this paper uses individual questionnaire items.

\section{Results}

\subsection{Defining plant roles}

Our cluster analysis leads to three resultant plant role clusters that are described in Table 1, in terms of their respective group centroid (mean) scores and the standard error (the $K$-means method was invoked from SPSS for Windows, 1994). This table also depicts the probability that one or more of the cluster means differs from another, for each of the five competitive priorities. The clusters differ from each other on three of the five competitive priorities at the 0.05 level of significance.

We describe these three clusters as 'innovators' (34\%), 'improvers' $(34 \%)$, and 'transitory multifocused' $(32 \%)$. Innovators emphasize new product and process innovation (and advanced innovation, though not significant), while paying reasonable attention to quality, flexibility, and price. Improvers focus on quality, while lagging on both innovation and flexibility. Finally, transitory multi-focused try to balance all competitive priorities, while not really doing very well on any of them (Skinner, 1974). As a result, these plants lag substantially on quality, while being good on flexibility and average on innovation. Thus, transitory multi-focused is not necessarily bad, simply that these plants are not optimally structured to be narrowly goal-oriented. Possibly,

Table 1

Competitive priorities by group: results of cluster analysis

\begin{tabular}{lllll}
\hline Competitive priority & \multicolumn{2}{l}{ Strategic plant role cluster } & Probability of $F$-ratio \\
\cline { 2 - 4 } & 1 & 2 & 3 \\
& Innovator & Improver & Multi-focused & 0.00001 \\
\hline QUALITY & $3.5(2,3)$ & $\mathbf{4 . 1}(1,3)$ & $1.5(1,2)$ & 0.00001 \\
FLEXIBILITY & $\mathbf{3 . 9}(2,3)$ & $1.75(1)$ & $2.3(1)$ & $\mathrm{ns}$ \\
PRICE & 3.0 & 2.7 & $\mathbf{3 . 0 6}$ & 0.0003 \\
INNOVATE & $\mathbf{3 . 3 3}(2,3)$ & $2.15(1)$ & $2.06(1)$ & $\mathrm{ns}$ \\
LEAD-INNOVATOR & $\mathbf{0 . 4 1}$ & 0.29 & 0.35 & \\
\hline
\end{tabular}

Numbers in parentheses indicate cluster numbers from which cluster is different (Scheffe pairwise test). ns $=$ Not significant. Bold numbers indicate highest score for cluster on that particular priority. 
these plants are undergoing some form of transition, or view the priorities as a tradeoff. Further analysis of these three clusters is presented in Section 3.3, where we compare performance and practices for these three groups.

\subsection{Regional comparisons on performance and practices}

Table 2 summarizes the regional comparisons of performance based on location. Though we could not obtain detailed cost data, the data on productivity, quality, and customer rejects are reliable and enable us to estimate regional performance. As Table 2 shows, plants in Japan still have a small lead in terms of quality (MAT-QUAL), productivity (PRODUCTIVITY), and customer rejects (REJECTS). The big surprise for us is the excellent performance of plants located in NICs. Furthermore, NIC-owned plants actually had higher quality performance than Japanese-owned plants. On all three dimensions NIC-located plants are second only to Japanese plants. On average, plants located in N. America and Europe, even though several of these are Japanese owned, do not perform as well as the plants located in Japan or NICs. However, if one examines the rates of improvement over the past 3-4 years (e.g., YLD-IMP), plants located in the NICs and N. America (and those owned by NIC and European companies) show the greatest improvements. This is consistent with the growing emergence of NICs and the ongoing rejuvenation of US plants. However, this should also be viewed in the context of the quality level from which the improvement is taking place (the overall yield in 1992, i.e., YLD_92). Except for China/Russia and Other (where yields would be lower than those shown in Table 2 after we correct for the lower standards), N. America had the lowest yields in 1992; naturally, there was greater scope for dramatic improvement.

Among bottom-line measures, capacity utilization (CAP-UTIL), is an interesting measure in that it reflects local political and economic conditions as much as anything else. The high Chinese/USSR capacity utilization is a result of centrally controlled quotas, and even overproduction; on the other hand, the high N. American figures reflect industry under capacity, suppression of imports due to import du-

Table 2

Factory performance by region (by location)

\begin{tabular}{|c|c|c|c|c|c|c|c|}
\hline \multirow[t]{2}{*}{ Performance measure } & \multicolumn{6}{|c|}{ Region of location } & \multirow[t]{2}{*}{ Probability of $F$-ratio } \\
\hline & $\begin{array}{l}1 \\
\text { N. America } \\
{[10]}\end{array}$ & $\begin{array}{l}2 \\
\text { Europe } \\
{[9]}\end{array}$ & $\begin{array}{l}3 \\
\text { Japan } \\
{[8]}\end{array}$ & $\begin{array}{l}4 \\
\text { NICs } \\
{[18]}\end{array}$ & $\begin{array}{l}5 \\
\text { China/Russia } \\
{[5]}\end{array}$ & $\begin{array}{l}6 \\
\text { Other } \\
{[4]}\end{array}$ & \\
\hline \multicolumn{8}{|l|}{ End outcomes } \\
\hline MAT-QUAL (\# /1000 tubes) & 1090 & 1106 & 1045 & 1071 & 1121 & 1127 & $\mathrm{~ns}$ \\
\hline REJECTS (ppm) & 4152 & 3922 & 2525 & 3666 & 10,000 & 6324 & 0.10 \\
\hline PRODUCTIVITY (Tubes /man-h) & 1.22 & 1.27 & 1.75 & 1.31 & 0.27 & 0.49 & 0.028 \\
\hline YLD_92(\%) & 73.7 & 81.0 & 86.2 & 83.1 & 75.2 & 76.4 & $\mathrm{~ns}$ \\
\hline YLD-IMP (\%/year) & 4.96 & 1.14 & 0.51 & 2.1 & 1.09 & 1.60 & ns \\
\hline \multicolumn{8}{|l|}{ Intermediate } \\
\hline W-I-P (hours) & $27.8(5)$ & 53.3 & $16.9(5)$ & $24.5(5)$ & $220(1,3,4)$ & 75 & 0.026 \\
\hline CYCLE TIME (hours) & 18.1 & 21.2 & 16.7 & 19.3 & 26 & 23 & ns \\
\hline SCREEN EQUIPMENT DOWN/wk & 3.1 & 5.4 & 2.9 & 4.3 & 5.1 & 3.0 & ns \\
\hline EXHAUST EQUIPMENT DOWN/wk & 0.6 & 1.51 & 0.51 & 0.51 & 2.6 & 0.75 & ns \\
\hline DURABILITY (hours) & 22,128 & 18,778 & 24,375 & 19,588 & 13,200 & 12,667 & ns \\
\hline \multicolumn{8}{|l|}{ Bottom line } \\
\hline ROI $(\%)$ & 6.9 & 1.2 & 6.16 & 1.63 & 14.3 & 9.9 & $\mathrm{~ns}$ \\
\hline CAP-UTIL (\%) & 91.4 & 85.1 & 88 & 80.7 & 98.7 & 68.7 & $\mathrm{~ns}$ \\
\hline
\end{tabular}

Number of plants in each region are given in brackets. Numbers in parentheses indicate region numbers from which the region is different (Scheffe pairwise test). ns = Not significant. Bold numbers indicate the two best scores on that particular performance measure. 
ties, and the economic upturn in 1992-1993. Returnon-investment (ROI) is, not surprisingly, highest for plants located in China/Russia and Other regions (India/S. America) (10-14\%). The first is likely a result of government price setting, while the latter reflects the limited capacity and expanding demand. Among the developed economies, factories in Japan and N. America show the highest ROI (6-7\%), while NIC and European factories have the lowest ROI (1-2\%). The low ROI of NIC and European factories can be explained by recent capital investments. NIC plants, in particular, appear to have made investments for the long term. The results on intermediate performance measures show insignificant differences across N. America, Europe, Japan, and NICs; the only notable result is the low workin-process in Japanese and NIC plants. Overall, plants located in or owned by Chinese/USSR or other countries still lag substantially behind the other four regions.

A few measures do stand out and deserve explanation. Japanese plants have the lowest work-in-process inventories, even though picture tube manufacturing is not a typical Toyota Production System (i.e., kanbans and just-in-time) type of setting. When it comes to equipment and maintenance issues ('screen or exhaust equipment down'), Japanese plants are the leaders, with NIC and N. American plants lagging behind. European plants are next on these measures with the remaining plants in China/Russia and other regions constituting the tail of the distribution.

Table 3 presents regional comparisons for factory priorities. The data indicate that Japanese plants emphasize quality (QUALITY) more than other regions. NIC and European plants do not emphasize quality as much. Flexibility (FLEXIBILITY) appears to be a higher priority for N. American and Japanese plants. European plants' lower emphasis on flexibility may be the result of a tendency to focus individual factories on either large or small tubes. When it comes to innovation (INNOVATE) - the ability and intent to make ongoing improvements in product and process design-Japanese plants are the clear leaders, with the plants in N. America, Europe, and NICs forming the second group, and the rest of the world making up the last group. Due to the fact that this industry is on the verge of a technological discontinuity, another dimension of competition is the ability to be a leader in such advanced innovations (LEADINNOVATOR). Here too, Japanese plants lead the others, but NIC plants demonstrate a clear desire to leapfrog the current leaders. Finally, price (PRICE) is another key competitive priority in this industry, and here, there is surprisingly equal emphasis throughout the world, except for plants in India and S. America, which are focused on low price.

Factory architectures vary throughout the world (Table 4a). For color tubes, NIC factories are the youngest in the world-8 years-compared to 23 for Japanese, 20 for N. American and European, and less than 15 for the others. In general, we found that NIC, N. American, and Chinese factories have the newest equipment. This is primarily because of recently established new factories, as in NICs, or installation of new equipment, as in N. America and China. US factories make the largest tubes on average. Japanese factories have a surprisingly low aver-

Table 3

Factory priorities by region (by location)

\begin{tabular}{|c|c|c|c|c|c|c|c|}
\hline \multirow[t]{3}{*}{ Priorities } & \multicolumn{6}{|c|}{ Region of location } & \multirow[t]{3}{*}{ Probability of $F$-ratic } \\
\hline & 1 & 2 & 3 & 4 & 5 & 6 & \\
\hline & N. America & Europe & Japan & NICs & China/Russia & Other & \\
\hline QUALITY & 3.3 & 2.33 & 4 & 2.9 & 3.7 & 2.3 & 0.087 \\
\hline FLEXIBILITY & 2.9 & 2.22 & 3.75 & 2.3 & 2.2 & 2.2 & 0.094 \\
\hline PRICE & 2.9 & 3 & 3 & 3 & 3.2 & 2.3 & ns \\
\hline INNOVATE & 2.37 & 2.5 & 3.29 & 2.39 & 2.2 & 1.6 & ns \\
\hline LEAD-INNOVATOR & 0.3 & 0.18 & 0.5 & 0.43 & 0.27 & 0.25 & 0.066 \\
\hline
\end{tabular}

Bold numbers indicate top two regions on that particular priority. One-way ANOVA results indicate differences across regions. ns $=$ Not significant. 
Table 4

(a) Factory architecture by region (by location)

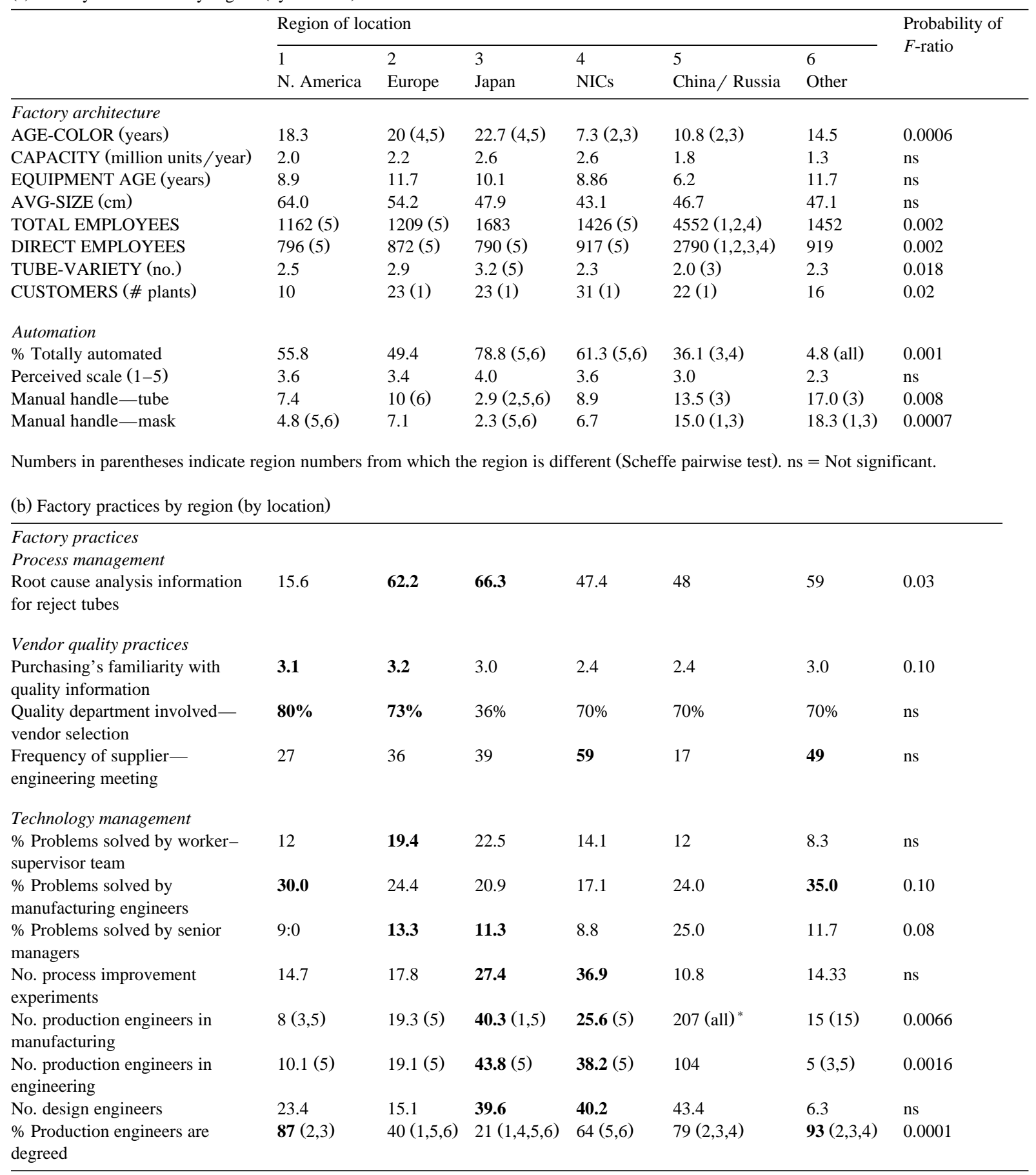


Table 4 (continued)

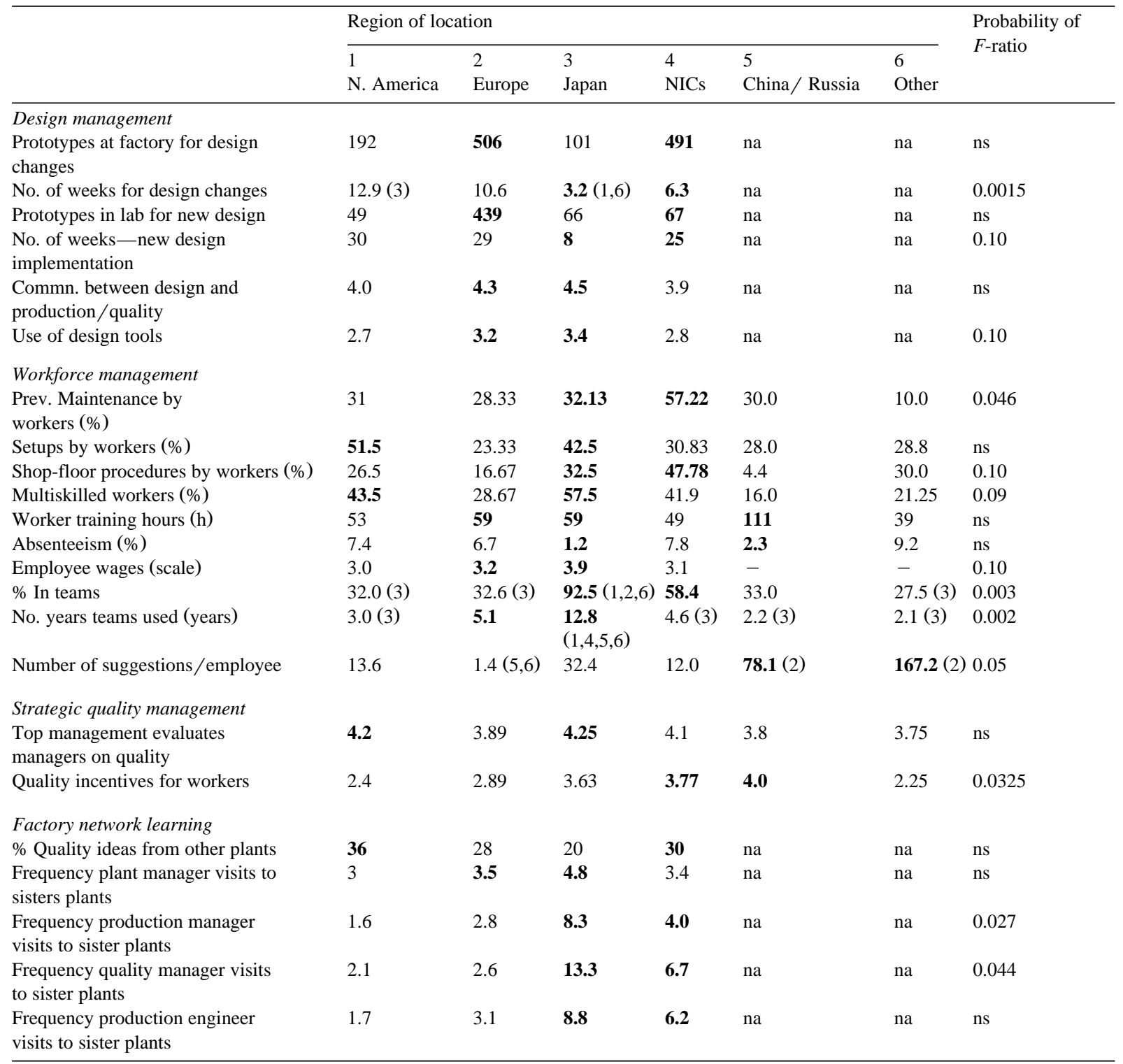

Numbers in parentheses indicate region numbers from which the region is different (Scheffe pairwise test). ns $=$ Not significant. Bold numbers are two best scores for each practice. na = Not Applicable; $-=$ Data not available.

$*$ cf. footnote 3 .

age tube size, possibly because they manufacture a large range of tube sizes, including some very small tube sizes, e.g., $10 \mathrm{in}$. The average size for European factories is low because of the inclusion of a couple of factories that focus on the East European market for small tubes. Japanese factories also produce on average the most tube sizes per factory and on any one line (3.2 sizes per line) which is consistent with their emphasis on flexibility. Yet, NIC factories serve the largest number of customers.

Japanese and NIC factories have the highest equipment automation, with Japanese factories hav- 
Table 5

Factory performance by cluster group

\begin{tabular}{|c|c|c|c|c|}
\hline \multirow[t]{2}{*}{ Performance measure } & \multicolumn{3}{|c|}{ Strategic plant role cluster } & \multirow[t]{2}{*}{ Probability of $F$-ratio } \\
\hline & $\begin{array}{l}1 \\
\text { Innovator } \\
{[17]}\end{array}$ & $\begin{array}{l}2 \\
\text { Improver } \\
{[17]}\end{array}$ & $\begin{array}{l}3 \\
\text { Multi-focused } \\
{[16]}\end{array}$ & \\
\hline \multicolumn{5}{|l|}{ End-outcomes } \\
\hline MAT-QUAL (\# /1000 tubes) & 1058 & 1094 & 1105 & 0.10 \\
\hline REJECTS (ppm) & 3930 & $2924(3)$ & $4862(2)$ & 0.04 \\
\hline YLD-IMP (\% / year) & 1.35 & 1.92 & 3.0 & ns \\
\hline \multicolumn{5}{|l|}{ Intermediate } \\
\hline W-I-P (hours) & 33 & 43 & 36 & ns \\
\hline CYCLE TIME (hours) & 18.8 & 26.7 & 21.0 & ns \\
\hline \multicolumn{5}{|l|}{ Bottom-line } \\
\hline ROI (\%) & 7.6 & 2.5 & 4.65 & ns \\
\hline CAP-UTIL. (\%) & 83.6 & 87.0 & 86.1 & $\mathrm{~ns}$ \\
\hline
\end{tabular}

The number of plants within each cluster are given in brackets. Numbers in parentheses indicate cluster numbers from which the cluster is different (Scheffe pairwise test). ns $=$ Not significant. Bold numbers indicate highest performing cluster on that particular performance measure.

ing the least amount of manual handling. Not surprisingly, several of the Chinese factories are set up to be highly automated, but still have substantial manual handling. The above numbers change somewhat when the factories are grouped by ownership rather than location. N. American- and European-owned factories are the oldest. The newest equipment is in plants owned by NIC, Japanese, and Chinese companies. NIC-owned plants make somewhat smaller tube sizes than Japanese or N. American/Europeanowned plants. Japanese-owned plants outside or within Japan manufacture the most variety of tube sizes. The pattern of automation by ownership is similar to that for location, except that Japaneseowned plants have a substantial lead over NICs as well.

Numerous comparisons of management and factory practices may be drawn from these data (Table 4b). However, given space limitations, we present only the key observations. Most regions appear to be equal on top management emphasis, except that in some regions this emphasis manifests itself in the form of financial and other incentives for quality and other objectives. NIC and Japanese factories appear to emphasize learning and technical knowledge, as indicated by the emphasis on experimentation and problem-solving at all levels, as well as the large number of engineers employed. ${ }^{4}$ Also, surprisingly, NIC factories appear to be at par with Japanese factories (and ahead of the other regions) in adopting state-of-the-art workforce practices such as multiskilled workers, broad worker responsibilities, and the use of teams (also see Whybark and Vastag, 1993). Thus, overall, Japanese and NIC factories appear to be the most progressive on factory management practices.

The above results suggest that Predictions 1a and $1 \mathrm{~b}$ are not fully supported, and in fact, are partially

\footnotetext{
${ }^{4}$ Chinese factories actually report that they have more engineers, but that is partly the result of the Chinese educational and vocational system which produces surplus engineers, coupled with the fact that there is no clear distinction between technicians and engineers. Also, the current start-up phase of most Chinese factories typically engages several dozen foreign engineers on site.
} 
Table 6

(a) Factory architecture by cluster group

\begin{tabular}{|c|c|c|c|c|}
\hline & \multicolumn{3}{|c|}{ Strategic plant role cluster } & \multirow[t]{2}{*}{ Probability of $F$-ratio } \\
\hline & Innovator & Improver & Multi-focused & \\
\hline AGE-COLOR (years) & 18 & 11 & 16 & ns \\
\hline CAPACITY (million units / year) & 2.8 & 2.03 & 2.15 & 0.10 \\
\hline EQUIPMENT AGE (years) & 9.9 & 8.8 & 10.6 & ns \\
\hline TOTAL EMPLOYEES & 1832 & 1105 & 1718 & $\mathrm{~ns}$ \\
\hline DIRECT EMPLOYEES & 1003 & 699 & 1146 & ns \\
\hline TUBE-VARIETY (no.) & $4.1(2,3)$ & $1.8(1)$ & $2.3(1)$ & 0.00001 \\
\hline CUSTOMERS (\# plants) & $37(2)$ & $16(1)$ & 25 & 0.04 \\
\hline \multicolumn{5}{|l|}{ Automation } \\
\hline Automation of data collection ( $1-5$ scale) & 3.12 & 3.3 & 2.8 & ns \\
\hline \multirow{2}{*}{\multicolumn{5}{|c|}{ Numbers in parentheses indicate cluster numbers from which the cluster is different (Scheffe pairwise test). ns = Not significant. }} \\
\hline & & & & \\
\hline \multicolumn{5}{|l|}{ Factory practice } \\
\hline \multicolumn{5}{|l|}{ Process management } \\
\hline Root cause analysis information for reject tubes & $60 \%$ & $36 \%$ & $46 \%$ & 0.10 \\
\hline \multicolumn{5}{|l|}{ Vendor quality practices } \\
\hline Purchasing's familiarity with quality information & 2.7 & 2.9 & 2.9 & ns \\
\hline \multicolumn{5}{|l|}{ Technology management } \\
\hline No. process improvement experiments & $39(2)$ & $12.5(1)$ & 24.8 & 0.07 \\
\hline No. production engineers in manufacturing & $48.3(3)$ & 22.2 & $8.9(1)$ & 0.05 \\
\hline No. production engineers in engineering & 42.2 & 28.1 & 17.2 & ns \\
\hline No. design engineers & 42.4 & 20.5 & 23.4 & ns \\
\hline$\%$ Production engineers are degreed & 44.5 & 69.8 & 63.4 & 0.10 \\
\hline \multicolumn{5}{|l|}{ Design management } \\
\hline Prototypes at factory for design changes & 223 & 514 & 247 & ns \\
\hline No. of weeks for design changes & 5.3 & 8.3 & 11.9 & 0.02 \\
\hline Prototypes in lab for new design & 61.8 & 84.7 & 246 & ns \\
\hline No. of weeks - new design implementation & 17.1 & 26.4 & 25.7 & ns \\
\hline Commn. between design and production/quality & 4.6 & 4.1 & 3.9 & 0.07 \\
\hline Use of design tools & 3.2 & 2.6 & 2.9 & ns \\
\hline \multicolumn{5}{|l|}{ Workforce management } \\
\hline Preventive maintenance by workers $(\%)$ & 41 & 43 & 23 & 0.10 \\
\hline Setups by workers $(\%)$ & 40 & 40 & 25 & $\mathrm{~ns}$ \\
\hline
\end{tabular}




\begin{tabular}{|c|c|c|c|c|}
\hline & \multicolumn{3}{|c|}{ Strategic plant role cluster } & \multirow[t]{3}{*}{ Probability of $F$-ratio } \\
\hline & $\overline{1}$ & 2 & 3 & \\
\hline & Innovator & Improver & Multi-focused & \\
\hline Multiskilled workers $(\%)$ & 45 & 44 & 27 & $\mathrm{~ns}$ \\
\hline Worker training hours (h) & 50 & 75 & 49 & ns \\
\hline High school education (\%) & 68.5 & 64.5 & 40 & 0.05 \\
\hline Employee wages (scale) & 3.35 & 3.4 & 3.0 & ns \\
\hline Few status differences & $3.5(3)$ & 3.4 & 3.0 & ns \\
\hline$\%$ In teams & 62 & 58 & 33 & 0.078 \\
\hline No. years teams used (years) & $\mathbf{9 . 3}(2,3)$ & $3.5(1)$ & $4.0(1)$ & 0.0037 \\
\hline Number of suggestions/employee & 52.5 & 12 & 5.5 & 0.10 \\
\hline Managers do not cooperate & $2.4(3)$ & 2.8 & $3.3(1)$ & 0.036 \\
\hline \multicolumn{5}{|l|}{ Factory network learning } \\
\hline$\%$ Quality ideas from other plants & 18.6 & 38.4 & 30.8 & 0.10 \\
\hline Frequency plant manager visits to sister plants & 4.1 & 3.1 & 3.05 & ns \\
\hline Frequency production manager visits to sister plants & 5.7 & 3.1 & 1.9 & 0.06 \\
\hline Frequency quality manager visits to sister plants & 10.1 & 3.8 & 2.65 & 0.028 \\
\hline Frequency production engineer visits to sister plants & 6.6 & 3.16 & 3.23 & 0.10 \\
\hline
\end{tabular}

Numbers in parentheses indicate cluster numbers from which the cluster is different (Scheffe pairwise test). ns $=$ Not significant. Bold numbers indicate best score on that particular practice.

disconfirmed. On Prediction 1a, there appears to be a convergence on many dimensions such as top management emphasis on quality, worker training, and recruitment practices. Contrary to expectations, NICs are better than average on both process performance and innovation. In fact, they are reasonably good, and have been improving for the past few years even though on factory priorities, they still appear to lag, and are possibly trying to understand what they should emphasize. Japanese plants are leaders on both innovation and process performance, which reinforces the commonly voiced belief that Japanese plants have taken the lead from US and European plants. Prediction $1 \mathrm{~b}$ is supported to the extent that Japanese plants are leaders on both technology and management practices, while, contrary to expectations, NICs are at par with or better than European and N. American plants. In fact, NICs score among the top two on nine of 17 practices (compared to 13 of 17 for Japanese, five of 17 for N. American, and three of 17 for European plants).

\subsection{Comparing performance and practices across plant roles}

Table 5 presents a comparison of performance by cluster group. For the end outcome performance measures, it is evident that innovators are the superior performers on almost every count: best on internal quality (MAT-QUAL); a close second best on external quality (REJECTS); and, highest on productivity (PRODUCTIVITY). This is surprising, given the traditionally observed tradeoff between innovation and constant performance (see, e.g., Hambrick, 1983 for evidence on the superior performance of businesses that are 'defenders' and 'analyzers' in contrast to the average performance of 'innovators'). Possibly, the emphasis on innovation at the plant level has learning benefits that overcome the drawbacks of 'confusion' (Hayes and Clark, 1986). The improvers seem to do consistently well on all quality-related dimensions. In fact, they have the best customer quality performance, though they lag on 
Table 7

Results of canonical discriminant analysis

\begin{tabular}{llcccc}
\hline \begin{tabular}{l} 
Canonical function \\
\cline { 1 - 3 }$\#$
\end{tabular} & Name & $\begin{array}{l}\text { Eigen value } \\
\text { or root }\end{array}$ & Canonical correlation & Significance of canonical correlation & Percent of variance \\
\hline 1 & quality improvement & 2.466 & 0.84 & $<0.00001$ & 57.16 \\
2 & customer scope & 1.848 & 0.81 & $<0.00001$ & 42.84
\end{tabular}

\begin{tabular}{|c|c|c|c|c|}
\hline \multirow{2}{*}{ Predictor set } & \multicolumn{2}{|c|}{ Canonical correlation } & \multicolumn{2}{|c|}{ Canonical coefficient } \\
\hline & Function 1 & Function 2 & Function 1 & Function 2 \\
\hline QUALITY & 0.97 & -0.07 & 1.0169 & -0.1567 \\
\hline FLEXIBILITY & 0.055 & 0.72 & -0.0031 & 0.9399 \\
\hline INNOVATE & 0.15 & 0.436 & 0.1650 & 0.7228 \\
\hline LEAD-INNOVATOR & -0.025 & 0.15 & -0.1264 & -0.1924 \\
\hline PRICE & -0.08 & 0.11 & 0.2082 & 0.2116 \\
\hline
\end{tabular}

Bold numbers indicate high loadings (weights) in canonical functions +0.40 .

Wilk's Lambda $=0.351 . F$-statistic for Wilk's Lambda $=47.11(p<0.00001)$.

productivity. This possibly reflects a distinct focus on quality where no compromises are made, and is possibly an intermediate phase in a transition towards plants that can simultaneously achieve high quality and productivity (see, e.g., the sandcone model of Ferdows and de Meyer, 1990). ${ }^{5}$ Finally, multi-focused plants lag on almost every dimension, except on yield improvements (YLD-IMP). This is possibly because they have the greatest scope for improving (YLD_92, i.e., the overall yield in 1992 is lowest for these plants).

The comparison of factory architecture and practices by cluster group (Table $6 \mathrm{a}$ and $\mathrm{b}$ ) shows a number of expected, as well as surprising patterns. As expected, innovators produce larger tubes, have the greatest tube variety, the most customers, and are fairly automated. It appears that these factories have partial automation (so that it is not 'totally' automated, but the overall automation is still higher than most other plants; this is possibly why these factories perceive themselves to be more highly automated than improver plants). Improver factories are highly

\footnotetext{
${ }^{5}$ The sandcone model suggests that manufacturing capabilities develop in a cumulative fashion, starting with quality, and then gradually adding on other capabilities until the business has other capabilities as well, such as delivery, flexibility, and price.
}

automated (on both total automation as well as the self-perception scale). Consistent with their quality focus, improvers have the best workforce practices, are employee focused, and conduct continuous improvement through inter-plant learning and transfer of best practices. Innovators focus on technological issues more than the other groups: they conduct many experiments, have a highly skilled technical workforce (both engineers and workers), and are cross-functional in their problem-solving approach. They make the best use of teams: possibly, being innovators, the use of administrative innovations comes easily to them.

\subsection{Canonical discriminant functions that explain plant roles}

We carried out a canonical discriminant analysis using the discriminant option in SPSS for Windows to describe the key factory capabilities and priorities that explain the above clustering (Green, 1978; Klecka, 1980; Tabachnik and Fidell, 1983). Given our sample size, and the number of clusters, two key discriminant functions were identified (Table 7a,b). These functions explain the clusters with a $98 \%$ accuracy or hit rate. As Table 7a shows, two significant canonical functions are identified, with innovation and quality being the two competitive priorities that are most significant in describing the canonical 


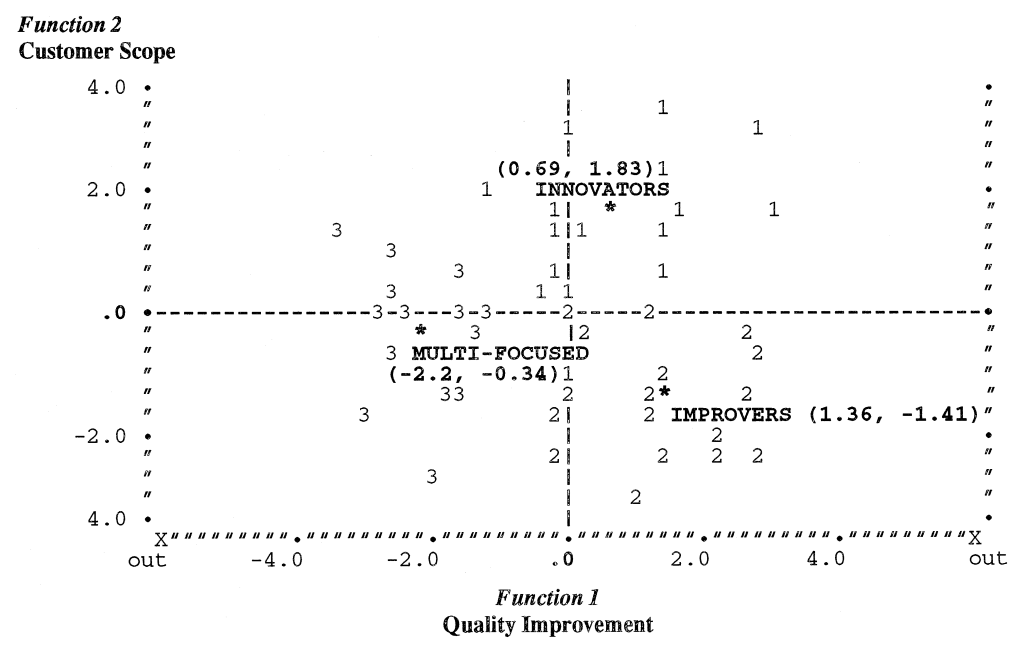

Fig. 2. Mapping plants and group centroids onto canonical function coordinates.

functions. The canonical correlations of 0.84 and 0.81 indicate that about $64 \%$ (average of square of 0.84 and 0.81 ) of the variance in plant role group membership is explained by the 5 competitive priorities (and vice versa). The overall significance of the multivariate relationship between the competitive priorities and the canonical functions is indicated by the $F$ statistic for Wilk's Lambda: $U=0.351, p(F)$ $<0.00001$. Thus, both discriminant functions are significant and have discriminating power (Klecka, 1980, p. 38).

The first canonical function appears to be a 'quality improvement' dimension that describes a plant's desire to achieve high quality. It is highly positively correlated with quality and very moderately with innovation. The second function is clearly focused on innovation and variety, driven by, what we call 'customer scope'. It represents a plant's desire to have a broad, innovative product offering, and its attempt to meet customer requirements to the extent possible. Though somewhat similar to Miller and Roth's 'market scope' function, 'customer scope', appropriately so, has more of a factory manufacturing emphasis. This function has high positive correlations with both innovation and flexibility, and a moderate correlation with both advanced innovation leadership and price. Thus, plants that emphasize quality are likely to be classified as 'quality improvement' plants. On the other hand, plants focus- ing on innovation and variety or flexibility are likely to have a high score on 'customer scope'. Fig. 2 maps plants onto the two plant role discriminant functions of 'quality improvement' and 'customer scope'. The centroids of each of the three clusters, innovators, improvers, and multi-focused are marked as ' $*$ '.

\subsection{Global distribution of plant roles}

Table $8 \mathrm{a}$ and $\mathrm{b}$ present results of a cross-tabulation of plant groups by region. Table 8 a presents the results where region represents location, and for Table $8 \mathrm{~b}$, region means ownership.

These results clearly do not support Prediction 2 . Neither the distribution of plants across a particular strategic plant role cluster, nor within a particular region (by location or by ownership), support the patterns expected if Prediction 2 is true (here, we use the classification of 'marketeers' and 'caretakers' in prior research to be a more generic classification, somewhat parallel to our categories of improvers and multi-focused; cf. Prediction 2.) None of the plants located in Japan, or owned by Japanese companies is multi-focused. Plants in Japan have the highest propensity to be innovators (six of eight, i.e., 75\%), followed by NICs (37\%), and N. American plants (30\%). The same numbers by ownership are $47 \%$ for Japan, 37\% for NICs, and 20\% for N. American- and 
Table 8

(a) Crosstabs of cluster group by region (by location)

\begin{tabular}{lcccc}
\hline Region & \multicolumn{2}{l}{ Strategic plant role cluster } & Total \\
\cline { 2 - 4 } & 1 & 2 & 3 & \\
& Innovator & Improver & Multi-focused & 10 \\
\hline (1) N. America & 3 & 4 & 3 & 9 \\
(2) Europe & 1 & 2 & 6 & 8 \\
(3) Japan & 6 & 2 & 0 & 16 \\
(4) NICs & 5 & 7 & 4 & 3 \\
(5) China/Russia & 1 & 2 & 0 & 4 \\
(6) Others & 1 & 0 & 3 & $\mathbf{5 0}$ of $\mathbf{5 4}$
\end{tabular}

(b) Crosstabs of cluster group by region (by ownership)

\begin{tabular}{lrrrc}
\hline (1) N. America/Europe & 3 & 3 & 9 & 15 \\
(3) Japan & 9 & 10 & 0 & 19 \\
(4) NICs & 4 & 2 & 5 & 11 \\
(5) China/Russia & 1 & 2 & 0 & 3 \\
(6) Others & 0 & 0 & 2 & 2 \\
Total & 17 & 17 & 16 & $\mathbf{5 0}$ of 54
\end{tabular}

European-owned plants. ${ }^{6}$ Plants located in and owned by European and N. American companies exhibit a high propensity to be multi-focused; nine of 19 plants located in the Western world, and nine of 15 plants owned by Western companies fall in this category (recall that we mentioned earlier that being multi-focused is not necessarily bad).

The plants located in or owned by the NICs display a mix among innovators, improvers, and multi-focused, showing an evolutionary phase in which there is no consistent pattern of plant roles for the region. However, five or six plants located in NICs (but not owned by NICs) are improvers. This means that Japanese or Western MNCs seem to be following the IPUP models to some extent, that is, not giving these plants an innovator role, thought still letting them be improvers. This is possibly the result of TQM efforts. Further support comes from the fact that of the eight innovators among Japanese-owned plants, five are in Japan itself. This confirms the popular view that Japanese companies

\footnotetext{
${ }^{6}$ The high fraction of innovator plants among NICs, and the correspondingly small number of multi-focused plants for NICs, suggests that NICs may have leapfrogged a management paradigm, directly going from having no presence in the industry only a few years ago to being among the industry leaders.
}

first carry out development and experiments in their home plants, and then 'export' these technologies to their overseas plants. This finding is not totally consistent with Ferdows' prediction (our Prediction 3) that over time, overseas plants will come to play a 'lead' role.

The results for the other regional groups are not surprising. None of the plants owned or located in non-NIC Asia or in S. America plays an innovator role. Among the plants in China and the ex-USSR, only one is multi-focused. There is one innovator, which is a slight surprise, yet, many political scientists, political economists, and country culture 'gurus' are willing to bet that China will not only be the fastest growing economy in the next couple of decades, but also that Chinese-owned companies can be expected to revolutionize world economics (see, e.g., Overholt, 1993).

Our analysis of plant roles on the basis of whether they are in the 'home' country or region, or 'away', provides less rigorous results because the sample sizes are small. Table $9 \mathrm{a}$ and $\mathrm{b}$ suggests that if the primary role of 'lead' plants is to be innovators, then 'home' plants have a larger fraction of innovators than 'away' plants (12 of 28 vs. 4 of 17). Surprisingly, however, this is not true for N. American and European plants. Thus, Prediction $3 \mathrm{a}$ is only partially supported. Most 'away' plants are improvers (10 of 
Table 9

(a) Plant roles by 'Home' or 'Away' ('Home' = Home country; 'Away' = not in home country)

\begin{tabular}{|c|c|c|c|c|c|}
\hline \multirow[t]{2}{*}{ Region } & \multirow[t]{2}{*}{ Home or away } & \multicolumn{3}{|c|}{ Strategic plant role cluster } & \multirow[t]{2}{*}{ Total plants } \\
\hline & & $\begin{array}{l}1 \\
\text { Innovator }\end{array}$ & $\begin{array}{l}2 \\
\text { Improver }\end{array}$ & $\begin{array}{l}3 \\
\text { Multi-focused }\end{array}$ & \\
\hline \multirow[t]{2}{*}{ (1) N. America } & Home & 0 & 0 & 1 & 1 \\
\hline & Away & 0 & 0 & 0 & 0 \\
\hline \multirow[t]{2}{*}{ (2) Europe } & Home & 1 & 0 & 2 & 3 \\
\hline & Away & 2 & 3 & 6 & 11 \\
\hline \multirow[t]{2}{*}{ (3) Japan } & Home & 6 & 2 & 0 & 8 \\
\hline & Away & 3 & 8 & 0 & 11 \\
\hline \multirow[t]{2}{*}{ (4) NICs } & Home & 4 & 2 & 3 & 9 \\
\hline & Away & 0 & 0 & 2 & 2 \\
\hline
\end{tabular}

(b) Plant roles by 'Home Region' or 'Away Region' ('Home' = Home region; 'Away' = not in home region)

\begin{tabular}{llllll}
\hline (1) N. America & Home & 0 & 0 & 1 & 1 \\
(2) Europe & Away & 0 & 0 & 0 & 0 \\
& Home & 2 & 1 & 6 & 9 \\
(3) Japan & Away & 1 & 2 & 0 & 5 \\
(4) NICs & Home & 6 & 2 & 0 & 8 \\
& Away & 3 & 2 & 11 & 10 \\
& Home & 4 & 0 & 1 & 1 \\
\hline
\end{tabular}

17), though these are mostly Japanese-owned plants. Multi-focused plants exist both at 'home' and 'away'. Though our cluster analysis does not match Ferdows' categories of plant roles, and thus Predictions $3 \mathrm{~b}$ and $3 \mathrm{c}$ cannot be evaluated directly, the fact that every multiplant MNC has a different distribution of roles, for 'home' and 'away' plants, suggests that these predictions do not hold completely. In particular, several innovators exist among 'away' plants, thus contradicting Prediction 3c. Further, we could not test the prediction about the evolution of plant roles. Thus, Predictions $3 a, 3 b$ and $3 c$ are only partially supported.

\section{Discussion}

Our arguments and empirical results suggest that the IPUP models need to be reassessed and extended. Changes in economic factors and management practices contribute to the limited relevance of these traditional internationalization models. These include the growing convergence of factor cost configurations of various national markets (Vernon, 1981;
Porter, 1990), technology transfer activities within MNCs (Vernon, 1981; Flaherty, 1986; Bartlett and Ghoshal, 1989), and the global awareness and adoption of management knowledge (Young, 1992). As the discussion below indicates, several of these reasons are interrelated, and it is the simultaneous evolution of several of these, that possibly explains why the IPUP models are no longer strongly supported.

\subsection{Possible explanations}

One possible explanation of the narrowing of this performance gap among plants derives from the observation that whereas industrialized countries seek natural resources or low cost labor (i.e., those resources in which their countries may be disadvantaged), developing countries often seek to acquire technology, the resource in which they are comparatively poorly endowed (see Dunning, 1988, p. 15). Over time, firms from NICs, LDCs and developing countries gradually acquire technology and skills, and if they have the opportunity, may achieve higher performance than industrialized countries. This argument is supported by Schmenner and Rho (1990), who found a strong technology emphasis by Korean 
plants. In fact, it is now a widely held belief that many of the countries in the world are catching up. As Hamel and Prahalad suggest, this is to be expected in a world where capital, technology, and managerial talent are internationally mobile (Hamel and Prahalad, 1994). They argue that " ... The unfettered capitalism of the Chinese Diaspora in Taiwan, Hong Kong, and southern China has produced an economic miracle every bit the equal of Japan's ..." (Hamel and Prahalad, 1994, p. 269). A similar conclusion is echoed by the International Motor Vehicle Program (IMVP) research on the auto industry (Womack et al., 1990): the traditional view, whereby the "... world economy advanced by moving the production of standardized, low-priced productssuch as small automobiles and trucks-to new mass-production factories in newly industrializing countries...", clashes with the push towards lean production worldwide (Womack et al., 1990, p. 260). This, they predict, will lead to a new world economic order in which there will be greater equality, and, as a result, an increased flow of products, but overall a regional balance of trade flows. The Korean auto industry confirms this view. Starting as low-cost exporters, Korean auto producers are beginning to compete on quality and performance, and have established production facilities in the US and Europe. " "... The idea of a company from a developing country building a major manufacturing facility in a highly developed, high-wage country would have been unthinkable..."' (Womack et al., 1990, p. 263).

An important outcome of global competition, and the pace of economic progress is that companies are increasingly having to adopt a more 'geocentric' (i.e., world-oriented) approach (Perlmutter, 1969). ${ }^{7}$ Here, it appears that actions are leading intents. Thus, while Japanese auto companies were traditionally perceived to lack a global perspective (Womack et al., 1990, p. 272), their actions-investments, technology transfer, component localization, and exports back to Japan-are indicative of a more geocentric outlook. This is confirmed by our global color picture tube data: innovator plants exist in both

\footnotetext{
${ }^{7}$ Perlmutter describes three MNC attitudes-ethnocentric (or home-country-oriented), polycentric (or host-country-oriented), and geocentric (or world-oriented).
}

home countries and 'away' countries (Table 9a and b).

This 'geocentrism' is closely connected with the notion of MNCs as a network of resources that require coordination (Porter, 1986; Hedlund, 1986; Bartlett and Ghoshal, 1989). MNCs are projected to be differentiated networks of independent but coordinated resources for subsidiaries (see, e.g., Bartlett and Ghoshal, 1989, p. 98), or for plants (see, e.g., Ferdows, 1989). Thus, the MNC's global network becomes one of interdependent and intelligent nodes, rather than one where strategic functions are clearly located in a center and the 'foreign' units are relegated to implementing roles (Hedlund, 1986; Bartlett and Ghoshal, 1989). ${ }^{8}$ This is confirmed by our data (Table 9a,b). Yet, we found that these plant roles do not follow Ferdows' expectations about plant roles. Two factors may explain this. First, increasing product maturity and rapidly improving telecommunication make it less critical to have a short spatial distance between production facilities and the corporation centers for decision-making and product development. It is thus possible to have 'lead' plants that are not in the MNC's home country. Second, these roles are redefined in the context of inter-related plant roles. Plants within a network can be strategically designed to be centers of excellence on different dimensions. This may preclude one plant from being a 'lead' plant (also, see Section 1.4).

Another potential explanation for our results and the partial disconfirmation of the IPUP model is the growing convergence of management practices resulting from the world-wide diffusion of management principles associated with just-in-time (JIT), total quality (TQM), lean production, cross-functional product development, and the use of CAD/CAM (Womack et al., 1990, pp. 227-255; Young, 1992; etc.). As such practices are adopted in different parts of the world, the performance of plants in different parts of the world can be expected to converge. This is not to say that such practices are easy to adopt and internalize: both the pace of

\footnotetext{
${ }^{8}$ Yet, even today there is a contradicting model, the 'home base' model. According to this model, the international dispersion of creative and strategic assets is seen as mostly ineffective, and a temporary side-effect of acquisition strategies (see Porter, 1990).
} 
change, e.g., at Gateway 2000 Computers (Agility Forum, 1995) and the 'stickiness' of such practices explain the difficulty of transfer of best practices (von Hippel, 1994; Szulanski, 1995).

\subsection{Discussion of the current theory}

While the IPUP models may have explained a great deal about international product and production loci in the past, the theory lacks adequate explanatory power today. Our analysis of regional differences in the global color picture tube industry provides evidence to this effect, and highlights limitations to extant descriptive models in the operations management literature. Further, the applicability of the IPUP models appears to be limited if new products are developed in companies that already have considerable operations in foreign countries (also see Vernon, 1979; Melin, 1992, p. 103).

We can begin to explain our results by extending the notion of an investment development path or cycle (Dunning, 1986). According to this (as yet untested) hypothesis:

FDI by or in a country '... will vary according to (i) its stage of economic development, (ii) the structure of its factor endowments and markets, (iii) its political and economic systems, and (iv) the nature and extent of market failure in the transaction of intermediate products across national boundaries...' (Dunning, 1988, p. 15). ${ }^{9}$

\footnotetext{
${ }^{9}$ The international development cycle model discussed above is, in some ways, a restatement and reinterpretation of classical theories of trade and international economics. Yet, given the intersection of capitalism-based international economics and communist/socialist theories, we may see further exceptions to existing theories. For example, Ohmae (1995) predicts the emergence of region-states such as Silicon Valley, San Diego-Tijuana, northern Italy, Baden-Wurttemberg, Singapore, Osaka-Kansai, Bangalore in India, and Hong Kong-southern China. Overholt suggests that China has reversed the traditional non-capitalist economic policy by putting light industry before heavy, and using the economic multiplier model to jump-start its economy (Overholt, 1993). Thus, the Chinese strategy of focusing on light industry, balancing government dictatorship with human resource management, developing a flexible working relationship with Hong Kong, and focusing on technical manpower for the future will likely catapult it to global leadership in the early 21 st century. Similar projections have been made for India (Ohmae, 1995), Poland, the ex-East German region of Germany, and even Russia.
}

Thus, a country's international FDI will pass through a number of stages (here, country refers to any country, not just industrialized countries). In Stage One, there will be no FDI, in or out, due to the lack of a political, commercial, and technological infrastructure for markets and support services, and the inability to leverage factor endowments. As the infrastructure improves in Stage Two, intermediate products will start to be imported, generally via the internal mechanisms of multinational enterprises because the transaction costs of external markets are too high. During Stage Three, the developing country's firms start to generate their own ownershipspecific advantages, and may go abroad seeking bigger markets, or supplementary resources. ${ }^{10} \mathrm{At}$ this point, the developing country may be starting on its journey to be a more developed and industrialized country. Countries such as Japan in the 1960s and 1970s, and Korea and Taiwan in the 1980s and 1990s, appear to have gone through this cycle of development. ${ }^{11}$ Due to limitations of space, we do not intend to describe how or why these countries were able to trigger their investment development paths while others were not (see, e.g., Heenan and Keegan, 1979; Schumacher, 1975, 1989; Morita et al., 1988; Womack et al., 1990, pp. 260-264; WooChoong, 1992). However, our results indicate that countries such as Korea and Taiwan do have superior practices and performance at the plant level, and also assign different roles for different plants. That is, they do not focus their plants simply to be improvers, but also have plants that are innovators.

From an operations strategy standpoint, there are unresolved conflicts between the internationalization models and the notion of progression of capabilities.

\footnotetext{
${ }^{10}$ Existing research indicates that a key reason for the internationalization of NIC companies is that NIC MNCs have better production expertise and better technical support than the host countries (generally LDC and developing countries) for low-technology products. Further, they tend to be more skillful than even developed countries in designing machinery for flexible use, and achieving high equipment utilization (Lau, 1992).

${ }^{11}$ Lau (1992) finds that, like the IPLC model, overseas roles tend to evolve over time: NIC MNCs tend to go from production to sales to marketing, in their overseas ventures.
} 
Until about 10 years ago, operations and business strategy researchers believed that there were tradeoffs between various competitive priorities (Skinner, 1974, 1978; Porter, 1980). This is also reflected in the theories developed by international business researchers, such as the notion that as the lifecycle progressed, it became difficult for plants to compete on more than just innovation, or quality, etc. Yet, if we look at today's technologies and management approaches, it is becoming increasingly clear that plants, business units, and companies can compete on multiple priorities (de Meyer et al., 1989; Fer- dows and de Meyer, 1990; Hamel and Prahalad, 1994). This too, affects the nature of global strategy models and the internationalization process. The ability of Japanese plants in the color picture tube industry to simultaneously achieve innovation, conformance and cost excellence, is one indication of the obsolescence of the notion of narrowly focused priorities for factories or business units.

\subsection{A need for new theory}

The foregoing argues for substantial modifications to existing IPUP models or the development of

Table 10

Old and new realities for defining plant roles in global manufacturing

\begin{tabular}{|c|c|c|}
\hline & IPUP models (yesterday) & New models (today) \\
\hline Primary drivers & $\begin{array}{l}\text { A. Access to local (relative to plant location) markets } \\
\text { B. Access to raw materials, and low skill, low labor } \\
\text { cost production capacity }\end{array}$ & $\begin{array}{l}\text { A. Access to markets (local, regional or global) } \\
\text { B. Access to raw materials, production capacity, highly } \\
\text { skilled or unskilled labor, and capital } \\
\text { C. Leverage network effects (e.g., within the company } \\
\text { or with suppliers or customers) }\end{array}$ \\
\hline \multirow[t]{6}{*}{$\begin{array}{l}\text { Implicit assump- } \\
\text { tions }\end{array}$} & $\begin{array}{l}\text { A. Governments are neutral or 'externalities' } \\
\text { B. Consumer desires are bifurcated: 'sophisticated' in } \\
\text { developed countries and 'unsophisticated' in less de- } \\
\text { veloped countries }\end{array}$ & $\begin{array}{l}\text { A. Governments are active participants in defining } \\
\text { which, how and where products are made and sold } \\
\text { B. Many countries have both 'sophisticated' and } \\
\text { 'unsophisticated' consumers }\end{array}$ \\
\hline & $\begin{array}{l}\text { C. Skills are bifurcated: high skilled and high cost in } \\
\text { developed countries; low skilled and low cost in less } \\
\text { developed countries }\end{array}$ & $\begin{array}{l}\text { C. Highly skilled people are found in significant } \\
\text { numbers in many less developed countries and low } \\
\text { skilled workers are found in large numbers in devel- } \\
\text { oped countries }\end{array}$ \\
\hline & $\begin{array}{l}\text { D. Technological adaptation follows a predictable } \\
\text { pattern }\end{array}$ & $\begin{array}{l}\text { D. Both product and process technological adaptation } \\
\text { can leap frog }\end{array}$ \\
\hline & $\begin{array}{l}\text { E. Competition is not a critical factor in defining plant } \\
\text { roles }\end{array}$ & $\begin{array}{l}\text { E. Global competitive dynamics should be considered } \\
\text { in defining idealized plant roles and do affect realized } \\
\text { roles }\end{array}$ \\
\hline & $\begin{array}{l}\text { F. MNCs are centralized; headquarters control knowl- } \\
\text { edge and information, and are all-powerful }\end{array}$ & F. MNCs are a network of differentiated capabilities \\
\hline & $\begin{array}{l}\text { G. Product life cycles are long enough to enable } \\
\text { internationalization process models to manifest them- } \\
\text { selves }\end{array}$ & $\begin{array}{l}\text { G. Product life cycles for many products are extremely } \\
\text { short }\end{array}$ \\
\hline \multirow{4}{*}{$\begin{array}{l}\text { Theoretical pre - } \\
\text { dictions and reali- } \\
\text { ties }\end{array}$} & $\begin{array}{l}\text { A. Innovate at home (i.e., do R\&D in a developed } \\
\text { country) }\end{array}$ & $\begin{array}{l}\text { A. Do critical R\&D primarily but not exclusively in } \\
\text { home country (developed or less developed) }\end{array}$ \\
\hline & $\begin{array}{l}\text { B. Use sophisticated process technologies at home, } \\
\text { outsource low tech labor intensive operations to less } \\
\text { developed countries; move mature technologies to less } \\
\text { developed countries }\end{array}$ & $\begin{array}{l}\text { B. Use sophisticated process technologies at home and } \\
\text { abroad; intentionally leapfrog when justified }\end{array}$ \\
\hline & $\begin{array}{l}\text { C. Treat plants as stand-alone or as part of vertically } \\
\text { integrated chain }\end{array}$ & $\begin{array}{l}\text { C. Treat plants as integral parts of value adding } \\
\text { networks }\end{array}$ \\
\hline & $\begin{array}{l}\text { D. Sell the most recently developed and sophisticated } \\
\text { products at home, sell mature and simpler products in } \\
\text { less developed countries }\end{array}$ & $\begin{array}{l}\text { D. Sell most recently developed 'global' products } \\
\text { globally; leapfrog product classes when conditions } \\
\text { justify }\end{array}$ \\
\hline
\end{tabular}


fundamentally new theory. Although it is beyond the scope of this paper to develop new theory, we present a framework in Table 10-using the categories Drivers, Assumptions, Predictions and Realitiesthat identifies major factors which we believe need to be dealt with in new theory development.

Drivers are the fundamental motivators for establishing plants outside a home country and making product decisions. Good theory should make explicit and justify what these drivers are. Excellent theory should be able to differentiate between what managers hope to do in this arena and what is realized. Economists have, for good reasons, focused on the realizations of FDI, etc., in IPUP theory development, but in so doing may have missed answering the 'why' question which we believe goes beyond seeking factor price advantages. For example, market and capacity aspirations are still important today, but with far broader applicable definitions of 'market' and 'capacity' based on the often complex and sometimes seemingly convoluted arrangements companies make today with customers and suppliers.

New theory should make its assumptions explicit and consistent with today's realities. A number of Implicit Assumptions underlying IPUP theory that were reasonably valid during the period 1950-1980 are very questionable today. For example, today 'customers' may be governments, competitors, or large middle classes in NICs, demanding and willing to pay for the latest in technology. Production 'partners' may be suppliers, governments or even competitors. Instead of hand-me-down technology transfer, some companies find it advantageous to upgrade their NIC plants with the next generation processes rather than implement them in their home country plants. Leapfrogging in consumer markets also takes place, e.g., NICs lacking a modern hardwired telecommunications infrastructure are bypassing this technology in favor of cellular systems.

Theoretical Predictions and Reality highlight the importance of predictive power to good theory, the reasonableness of fit previously provided by IPUP models, and the gap that now must be addressed by alternative models. The new models must also eliminate the ethnocentric bias inherent in the IPUP models. With the Chinese government owning plants in the US, and South Korean companies owning plants in Germany (just two of many such examples of
NICs reversing the 'normal' IPUP investment pattern), the new models need to be geocentric in orientation to have much predictive power.

\section{Summary and conclusions}

The structure and nature of global manufacturing is changing and is not fully explained by existing international economics, international business, or operations strategy theories. Understanding this change is necessary for both academics who desire to conduct leading-edge research in this area, as well as managers and firms who are involved with day-today decision-making. While managerial and academic understanding of the realities of international competition has gone beyond the IPUP models, the theoretical and empirical bases have not progressed much beyond these initial efforts (a key exception is Porter, 1990).

The IPUP models, as applied to manufacturing, need to be modified in the context of global economic changes, international factory roles, worldwide diffusion of management knowledge, and the increasing feasibility of achieving multiple competitive priorities. This research provides a step in that direction by combining viewpoints from international business and operations strategy with detailed empirical results from the global picture tube industry.

\section{References}

Agility Forum, 1995. Meeting of the Marketing and Logistics Executive Development Research Group, December 5-6, Chicago, IL.

Anderson, P., Tushman, M., 1990. Technological discontinuities and dominant designs: a cyclical model of technological change. Adm. Sci. Q., December.

Anderson, J.C., Cleveland, G., Schroeder, R.G., 1989. Operations strategy: a literature review. J. Operations Manage. 8, 133-158.

Bartlett, C.A., Ghoshal, S., 1989. Managing Across Borders: the Transnational Solution. Harvard Business School Press, Boston, MA.

Benson, P.G., Saraph, J.V., Schroeder, R.G., 1991. The effects of organizational context on quality management: an empirical investigation. Manage. Sci. 37, 9.

Chew, W.B., Bresnahan, T.F., Clark, K.B., 1989. Measurement, coordination, and learning in a multiplant network. In: Kaplan, 
R. (Ed.), Measures for Manufacturing Excellence. Harvard Business School Press, Boston, pp. 129-162.

de Meyer, A., Miller, J.G., Nakane, J., Ferdows, K., 1989. Flexibility: the next competitive battle. Strategic Manage. J. 10 (2), 135-144.

Dunning, J.H., 1986. The Investment Development Cycle and Third World Multinationals. Francis Porter, London.

Dunning, J.H., 1988. The eclectic paradigm of international production: a restatement and some possible extensions. J. Int. Business Studies 19.1, 1-31.

Ferdows, K., 1989. Mapping international factory networks. In: Ferdows, K. (Ed.), Managing International Manufacturing. North-Holland, Amsterdam.

Ferdows, K., de Meyer, A., 1990. Lasting improvements in manufacturing performance: in search of a new theory. J. Operations Manage. 9, 168-184.

Flaherty, M.T., 1986. Coordinating international manufacturing and technology. In: Porter, M.E. (Ed.), Competition in Global Industries. Harvard Business School Press, Boston, MA.

Garvin, D., 1988. Managing Quality. The Free Press, New York, NY.

Green, P.E., 1978. Analyzing Multivariate Data. Dryden Press, Hinsdale, IL.

Hamel, G., Prahalad, C.K., 1985. Do you really have a global strategy? Harvard Business Rev., July-August, 139-148.

Hamel, G., Prahalad, C.K., 1994. Competing for the future: breakthrough strategies for seizing control of your industry and creating the markets of tomorrow. Harvard Business School Press, Boston, MA.

Hambrick, D.C., 1983. Some tests of the effectiveness and functional attributes of Miles and Snow's types. The Academy of Management Journal 26, 5-26.

Hayes, R.H., Clark, K.B., 1986. Why some factories are more productive than others? Harvard Business Rev., SeptemberOctober, 66-73.

Hayes, R.H., Wheelwright, S.C., 1984. Restoring our Competitive Edge. Wiley, New York.

Hedlund, G., 1986. The hypermodern MNC - a heterarchy? Human Resour. Manage., Spring, 9-35.

Heenan, D.A., Keegan, W.J., 1979. The rise of third world multinationals. Harvard Business Rev., January-February, 101-109.

Hill, T., 1989. Manufacturing Strategy: Text and Cases. R.D. Irwin, Homewood, IL.

von Hippel, E., 1994. Sticky information and the locus of problem solving: implications for innovation. Manage. Sci. 40, 429439.

Hymer, S.H., 1976. The International Operations of National Firms: a Study of Direct Investment. MIT Press, Cambridge, MA.

Johanson, J., Vahlne, J.-E., 1977. The internationalization process of the firm-a model of knowledge development and increasing foreign commitments. J. Int. Business Studies 8, 23-32.

Johanson, J., Vahlne, J.-E., 1990. The mechanism of internationalization. Int. Marketing Rev. 7 (4), 11-24.

Keller, P.A., 1991. The Cathode-Ray Tube: Technology, History, and Applications. The Palisades Press, New York, NY.
Khurana, A., 1994. Quality in the Global Color Picture Tube Industry: Managing Complex Industrial Processes. PhD dissertation. University Microfilms, The University of Michigan, Ann Arbor, MI.

Klecka, W.R., 1980. Discriminant Analysis. Sage Publications, Newbury Park, CA.

Kojima, K., 1978. Direct Foreign Investment. Croom Helm, London.

Kojima, K., 1982. Macroeconomic versus international business approach to foreign direct investment. Hitosubashi J. Econ. 23, $1-19$.

Lau, Ho-Fuk, 1992. Internationalization, Internalization, or a New Theory for Small, Low-technology Multinational Enterprises? European Journal of Marketing 26 (10), 17-30.

Melin, L., 1992. Internationalization as a strategy process. Strategic Manage. J. 13, 99-118.

Miles, R.E., Snow, C.C., 1978. Organizational Strategy, Structure and Process. McGraw-Hill, New York.

Miller, D., Friesen, P.H., 1977. Strategy making in context: ten empirical archetypes. J. Manage. Studies 14, 253-280.

Miller, J.G., Roth, A., 1994. A taxonomy of manufacturing strategies. Manage. Sci. 40 (3), 285-304.

Mintzberg, H., 1978. Patterns in strategy formulation. Manage. Sci. 9, 934-948.

Mintzberg, H., 1992. The fall and rise of strategic planning. Harvard Business Rev. 72, 107-114.

Morita, A., Reingold, E.M. Shimomura, M., 1988. Made in Japan: Akio Morita and Sony. Signet, New York, NY.

Ohmae, K., 1985. Triad Power. The Free Press, New York.

Ohmae, K., 1995. Putting Global Logic First, Harvard Business Review, January.

Overholt, W.H., 1993. The Rise of China: How Economic Reform is Creating a New Superpower. W.W. Norton, New York, NY.

Perlmutter, H.V., 1969. The tortuous evolution of the multinational corporation. Columbia J. World Business, 9-18.

Porter, M.E., 1980. Competitive Strategy. The Free Press, New York.

Porter, M.E., 1986. Competition in Global Industries. Harvard Business School Press, Boston, MA.

Porter, M.E., 1990. The Competitive Advantage of Nations. Macmillan, London.

Richardson, P.R., Taylor, A.J., Gordon, J.R.M., 1985. A strategic approach to evaluating manufacturing performance. Interfaces $15,15-27$.

Schmenner, R.W., 1991. International factory productivity gains. J. Operations Manage. 10, 229-254.

Schmenner, R.W., Rho, B.H., 1990. An international comparison of factory productivity. Int. J. Operations Production Manage. 10 (4), 16-31.

Schonberger, R.J., 1986. World Class Manufacturing. The Free Press, New York, NY.

Schumacher, E.F., 1975. Small is Beautiful: Economics as if People Mattered. Harper and Row, New York, NY.

Schumacher, E.F., 1989. Small is Beautiful: Economics as if People Mattered. Harper and Row, New York, NY.

Skinner, W., 1969. Manufacturing: Missing Link in Corporate Strategy. Harvard Business Rev., 136-145. 
Skinner, W., 1974. The Focused Factory. Harvard Business Rev., May-June, 113-121.

Skinner, W., 1978. Manufacturing in the Corporate Strategy. Wiley, New York, NY.

SPSS for Windows, 1994.

Suarez, F.F., Utterback J.M., 1995. Innovation, Competition, and Industry Structure. Research Policy.

Szulanski, G., 1995. Unpacking Stickiness: An Empirical Investigation of the Barriers to Transfer Best Practice Inside the Firm. The Academy of Management Best Paper Proceedings, 437-441.

Tabachnik, B.G., Fidell L.S., 1983. Using Multivariate Statistics. Harper and Row, New York, NY.

Taylor, W., 1991. The Logic of Global Business: an Interview with ABB's Percy Barnevik. Harvard Business Rev., MarchApril, 91-105.

Vernon, R., 1966. International investment and international trade in the product cycle. Q. J. Econ., May, 190-207.

Vernon, R., 1971. Sovereignty at Bay: the Multinational Spread of US Enterprises. Basic Books, New York.
Vernon, R., 1974, The Location of Industry. In: Dunning, J. (Ed.), Economic Analysis and the Multinational Enterprise. George Allen and Unwin, London.

Vernon, R., 1979. The product cycle hypothesis in a new international environment. Oxford Bull. Econ. Stat. 41, 255-267.

Vernon, R., 1981. Sovereignty at bay: ten years after. Int. Organization 35, 517-529.

Wheelwright, S.C., 1978. Reflecting corporate strategy in manufacturing decisions. Business Horizons, February, 57-66.

Whybark, D.C. Vastag, G., 1993. Global Manufacturing Practices. Elsevier, Amsterdam.

Womack, J.P., Jones, D.T., Roos, D., 1990. The Machine that Changed the World. Macmillan, New York, NY.

Woo-Choong, K., 1992. Every Street is Paved with Gold. Times Books International, Singapore.

Wrapp, H.E., 1967. Good Managers Don't Make Policy Decisions. Harvard Business Rev., September-October.

Young, S.M., 1992. A framework for successful adoption and performance of Japanese manufacturing practices in the United States. Acad. Manage. Rev. 17 (4), 677-700. 